\title{
GASTRITELE ŞI HELICOBACTER PYLORI LA COPIL - DIAGNOSTICUL ENDOSCOPIC PRIMAR ŞI SECUNDAR
}

\author{
V.V. Lupu ${ }^{1}$, Gabriela Păduraru ${ }^{1}$, Ancuța Ignat ${ }^{1}$, Eliza Tighici-Saizu ${ }^{2}$, \\ Claudia Olaruㅁ, Nicoleta Gimiga ${ }^{1}$, Angelica Cristina Marin ${ }^{1}$, Cornelia Săvescu1, \\ Ioana Florea ${ }^{1}$, Marin Burlea ${ }^{1}$ \\ 'Disciplina de Pediatrie, Universitatea de Medicină şi Farmacie „, Gr. T. Popa “, Iaşi \\ ${ }^{2}$ Spitalul Județean de Urgență, Vaslui
}

\begin{abstract}
REZUMAT
Infecția cu Helicobacter pylori (H. pylori) este o problemă comună şi semnificativă de sănătate publică. Obiectiv. Determinarea prevalenței infecției cu H. pylori la copiii cu simptomatologie sugestivă şi conturarea cazurilor în funcție de tipul şi felul gastritei prin efectuarea de endoscopii digestive superioare. Material şi metodă. Studiu retrospectiv realizat pe o perioadă de 5 ani pe 1.269 de copii cu simptomatologie gastrică, la care s-au efectuat endoscopii cu biopsie, stabilindu-se rata de infecție cu $H$. pylori prin examen direct sau testul ureazei. Rezultate. Frecvența $H$. pylori în cazul gastritei acute a fost semnificativ mai mică $(34,78 \%)$ comparativ cu frecvența acesteia în cazul gastritei cronice (54,94\%). În cadrul celor 10 tipuri de gastrită, cele mai frecvente sunt formele purpurice $(43,66 \%)$, nodular purpurică $(25,93 \%)$ şi nodular antrală $(15,84 \%)$, la polul opus situându-se gastrita atrofică şi hipertrofică. Asocierile cele mai frecvente decelate endoscopic sunt cu esofagita gr I în $51,6 \%$, duodenita în $45,07 \%$ şi forma purpurică în $24,74 \%$.

Concluzii. Infecția cu $H$. pylori este cel mai frecvent asociată gastritei cronice $(54,94 \%)$. Identificarea precoce a infecției este esențială pentru eradicarea bacteriei şi prevenirea apariției diferitelor tipuri de gastrită identificate endoscopic.
\end{abstract}

\section{INTRODUCERE}

Helicobacter pylori (H. pylori) este una dintre cele mai frecvente infecții bacteriene cronice la nivel mondial şi se estimează că, în prezent, aproximativ jumătate din populația lumii este infectată cu această bacterie $(1,2)$. H. pylori cauzează gastrită cronică activă atât la adulți, cât şi la copii (3) şi este puternic asociată cu ulcerul peptic, atrofie, metaplazie intestinală şi cancer gastric la adulți (4).

A fost demonstrat rolul H. pylori în patogenia gastritelor şi corelația pozitivă a prezenței infecției $\mathrm{cu}$ prevalența gastritelor şi ulterior cu patologia specifică a adultului. Identificarea precoce a infecției este esențială pentru eradicarea bacteriei şi prevenirea apariției diferitelor tipuri de gastrită identificate endoscopic.

\section{OBIECTIV}

Stabilirea frecvenței infecției cu H. pylori în populația pediatrică şi conturarea cazurilor în funcție de tipul şi felul gastritei într-un lot semnificativ de copii prin efectuarea endoscopiei digestive superioare cu prelevarea de biopsii în prezența manifestărilor clinice specifice.

\section{MATERIAL ŞI METODĂ}

Studiu retrospectiv pe o perioadă de 5 ani asupra unui lot de 1.269 de copii, cu vârste cuprinse între 1-18 ani, diagnosticați cu gastrită în urma anamnezei, examenului clinic şi paraclinic în Clinica a V-a Pediatrie (Gastroenterologie) din cadrul Spitalului Clinic de Urgență pentru Copii „Sf. Maria” din Iaşi. 


\section{Tehnica efectuării endoscopiei digestive supe-} rioare:

- În clinica noastră copiii mari sunt examinați după un repaus digestiv de 8-10 ore, iar copiii mici (4 ani) după un repaus de 6 ore.

- La copiii mici, sub vârsta de 10 ani, am utilizat anestezie generală cu IOT, în serviciul nostru utilizându-se propofol în doză de 2 $\mathrm{mg} / \mathrm{kg}$.

- În perioada studiului, pentru sedare s-a folosit Dormicum, în doză de 0,15-0,20 mg/kg, Midazolam, 0,1-0,2 $\mathrm{mg} / \mathrm{kg}$, i.v.

- Pacienții sunt aşezați în decubit lateral stâng, cu capul în semiflexie şi genunchii flectați.

- În cavitatea bucală, între arcadele dentare se introduce o piesă bucală, cu scopul de evitare a endoscopului pe parcursul examenului.

Prin endoscopie se examinează segmentele parcurse şi se pot preleva mai multe biopsii de mucoasă gastrică în regiunea antrală (la $2 \mathrm{~cm}$ în jurul pilorului) şi în regiunea fundică, pentru a pune în evidență prezența $H$. pylori.

Punerea în evidență a bacteriei se face fie prin examen direct, fie prin cultură sau prin căutarea activităţii ureazei.

La o parte dintre pacienți s-au efectuat teste serologice pentru detectarea anticorpilor anti- $H$. pylori de tip IgG, precum şi teste salivare.

Din studiu au fost excluşi copiii care s-au prezentat pentru efectuarea endoscopiei digestive superioare de control, pentru cofirmarea eficacităţii tratamentului. Un alt criteriu de excluderea a fost reprezentat de anamneza pozitivă pentru consumul de antiiflamatoare nonsteroidiene.

În cadrul acestei cercetări s-a folosit pentru prelucrarea statistică a datelor programul STATISTICĂ, dedicat cercetării medicale.

\section{REZULTATE}

Pe baza sistemului Sydney, ce permite recunoaşterea a trei tipuri de gastrite care sunt entităţi clinico-morfologice: gastrita acută, gastrita cronică, gastrite speciale, am urmărit frecvența în lotul studiat în funcție de această clasificare. S-a constatat o frecvență ridicată a cazurilor cu gastrită acută $(68,67 \%)$, în timp ce cazurile cu gastrită cronică au reprezentat $31,13 \%$.

Deşi în proporție superioară, în cazul gastritei acute frecvența $H$. pylori a fost semnificativ mai mică $(34,78 \%)$ comparativ cu frecvența acestuia în cazul gastritei cronice (54,94\%) (Tabelul 1).
TABELUL 1. Evaluarea asocierii Helicobacter pylori vs. tip gastrită

\begin{tabular}{|l|c|c|c|}
\hline \multirow{2}{*}{ Gastrită } & \multicolumn{2}{|c|}{ Helicobacter pylori } & \multirow{2}{*}{ Total } \\
\cline { 2 - 3 } & Cu HP & Fără HP & \\
\hline \multirow{2}{*}{ Acută } & 304 & 570 & \multirow{2}{*}{874} \\
\cline { 2 - 3 } & $34,78 \%$ & $65,22 \%$ & \\
\hline \multirow{2}{*}{ Cronică } & 217 & 178 & \multirow{2}{*}{395} \\
\cline { 2 - 3 } & $54,94 \%$ & $45,06 \%$ & \\
\hline Total & $\mathbf{5 2 1}$ & $\mathbf{7 4 8}$ & $\mathbf{1 2 6 9}$ \\
\hline
\end{tabular}

Analiza a demonstrat asocierea semnificativă dintre $H$. pylori şi gastrita cronică $\left(\chi^{2}=45,66\right.$, $\mathrm{r}=-0,539, \mathrm{p}<<0,05,95 \% \mathrm{CI})$.

În urma endoscopiei, distribuția cazurilor în funcție de tipul gastritei remarcă frecvența crescută a cazurilor cu gastrită purpurică $(43,66 \%)$, gastrită nodular purpurică $(25,93 \%)$ şi gastrită nodular antrală $(15,84 \%)$. La polul opus, cu frecvențe foarte mici, se regăseşte gastrita nodular aftoidă $(0,16 \%)$, gastrita atrofică $(0,24 \%)$ şi gastrita hipertrofică (1,65\%). Frecvențe sub $10 \%$ au fost întâlnite pentru gastrita erozivă $(4,73 \%)$, gastrita difuză $(4,02 \%)$ şi gastrita erozivă şi hemoragică $(4,02 \%)$.

Tipurile de gastrite au fost analizate în funcție de tipul acestora - cronice sau acute (Fig. 1).

În urma endoscopiei digestive superioare s-au identificat şi alte patologii la nivelul esofagului, stomacului sau duodenului (Fig. 2).

Cel mai frecvent diagnostic secundar (endoscopic) a fost esofagită gradul I (51,6\%), fiind urmat de duodenită difuză $(45,07 \%)$, duodenită purpurică $(24,74 \%)$ şi esofagită gradul II $(23,17 \%)$.

\section{DISCUȚII}

Pentru efectuarea endoscopiei digestive superioare, principalele indicații au fost reprezentate de durerile abdominale recurente, hemoragie digestivă superioară, epigastralgii, vărsături recurente.

Durerea abdominală recurentă se referă la episoade de dureri abdominale îndeajuns de severe încât să afecteze activitatea zilnică a copilului. Este demonstrată de 3 sau mai multe episoade într-o perioadă de 3 luni (5).

Pe loturi diverse, copiii infectați nu prezintă mai des dureri abdominale decât cei neinfectaţi (6).

Este unanim acceptat că infecția cu $H$. pylori este principalul factor etiologic pentru gastrită şi ulcerul peptic (7). Prevalența infecției cu $H$. pylori diferă însă în funcție de vârstă şi de la o regiune la alta. În Statele Unite, pozitivitate $H$. pylori la copiii care au mai puțin de 10 ani este mai mică de $5 \%$, în rândul adulţilor de 20 de ani şi de peste 60 de ani pozitivitatea este de $10 \%$ şi respectiv $60 \%$ (8). În 


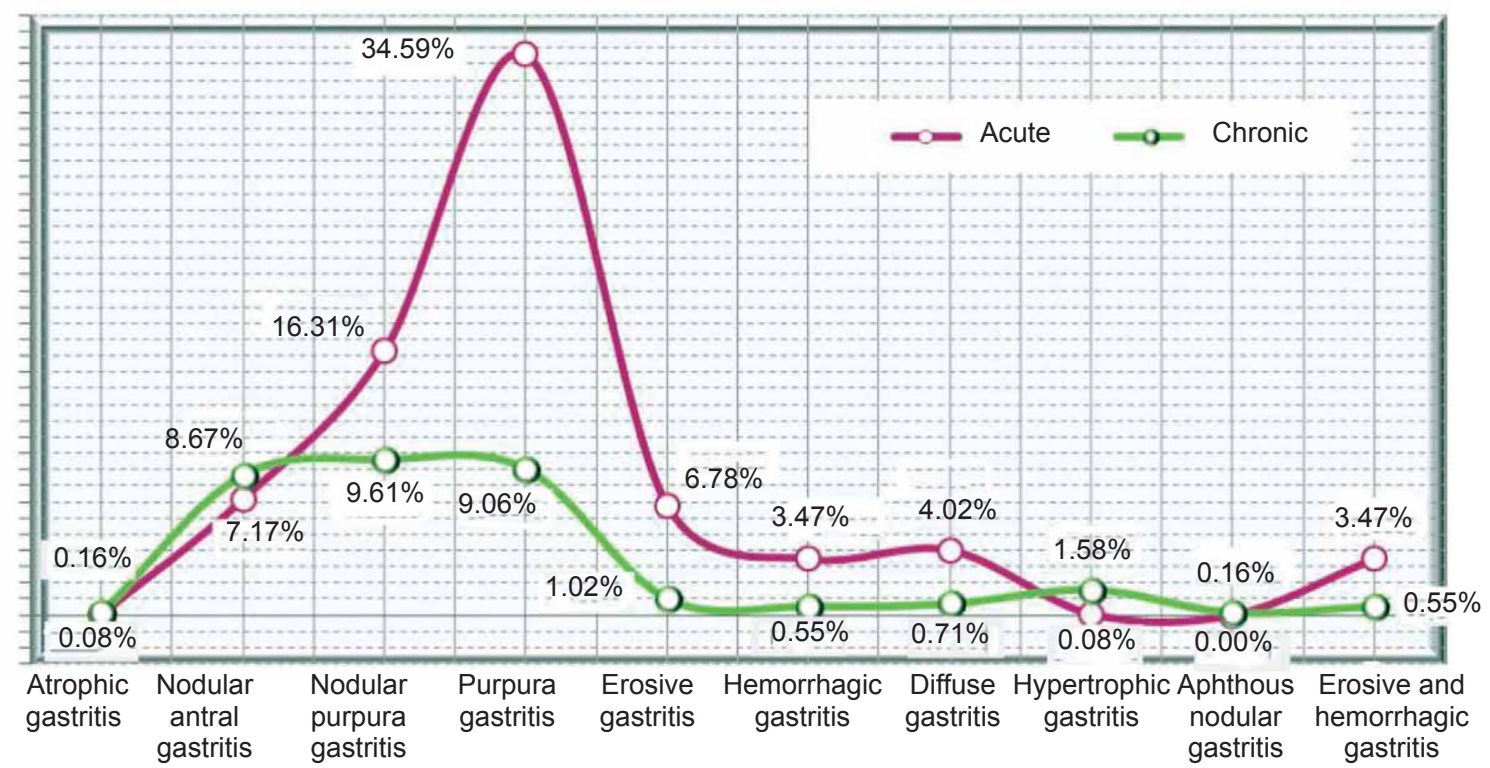

FIGURA 1. Distribuția cazurilor în funcție de tipul şi felul gastritei

\section{Secondary endoscopy diagnosis}

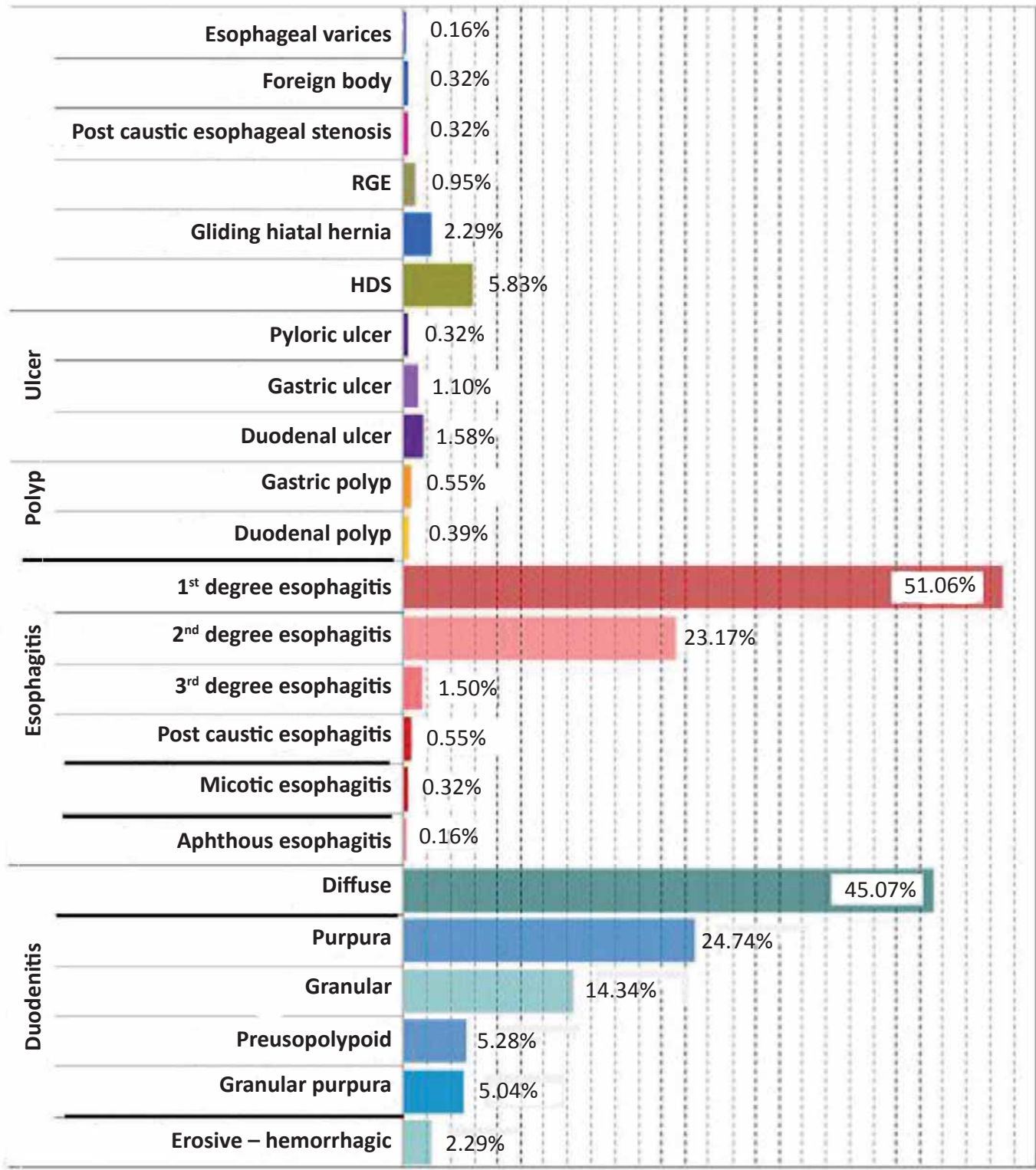


Japonia, prevalența infecției cu $H$. pylori a fost de $29 \%$ în rândul persoanelor cu vârsta cuprinsă între 15-19 ani (9). În Italia, prevalența H. pylori în rândul copiilor cu vârstă mai mică de 12 ani a fost de 34\% (10). În Bangladesh, Mahalanabis et al. au studiat 469 de copii cu vârsta cuprinsă între 6-9 ani şi au constatat că $H$. pylori este prezent la $84 \%$ dintre aceştia (11). În studiul de faţă am găsit un rezultat moderat, $34,78 \%$ în cazul gastritei acute şi $54,94 \%$ în cazul gastritei cronice.

Urmărirea unui lot de 275 de copii cu vârsta cuprinsă între 1 şi 15 ani, care acuzau diferite manifestări gastrointestinale, a evidențiat prezența infectiei cu $H$. pylori în $23,6 \%$ dintre cazuri, constatare care a sugerat faptul că infecția cu $H$. pylori este o problemă epidemiologică în acea zonă şi impunând explorarea specifică a tuturor copiilor cu tulburări gastrointestinale ca şi a fiecărui membru al familiei (12).

Într-un studiu efectuat pe 328 de pacienţi diagnosticați cu infecție cu $H$. pylori, gastrita nodulară a fost cea mai frecventă $(50,6 \%)(13)$.

În cazul celor 1.269 de copii luaţi în studiu, distribuția cazurilor în funcție de tipul gastritei remarcă frecvența crescută a cazurilor cu gastrită purpurică $(43,66 \%)$, gastrită nodular purpurică $(25,93 \%)$ şi gastrită nodular antrală $(15,84 \%)$.

Investigând relația dintre infecția cu H. pylori şi boala de reflux erozivă la copii pe un lot de 206 copii, s-a evidențiat o prevalență a esofagitei erozive de $23,8 \%$ la pacienţii cu infecție cu $H$. pylori şi
41,3\% la cei fără infecție; nu s-au găsit asocieri statistic semnificative între infecția cu $H$. pylori şi esofagita erozivă (14).

Rezultatele endoscopiei digestive superioare într-un studiu prospectiv pe 2 ani, pe 150 de copii au fost normale la 24 de pacienți (16\%), hernie hiatală la 30 de pacienți $(20 \%)$, diferite grade de esofagită la 60 de pacienți (40\%), eroziuni esofagiene la 39 de pacienți (26\%), gastrită eritematoasă la 51 de pacienți (34\%), gastrită nodulară la 45 de pacienți (30\%), ulcer gastric la 9 pacienți $(6 \%)$, ulcer duodenal la 3 pacienți (2\%) (15).

De asemenea, obținerea în studiul de față a esofagitei gradul I ca fiind cel mai frecvent diagnostic secundar endoscopic nu s-a putut corela semnificativ cu infecția cu $H$. pylori.

\section{CONCLUZII}

Infecția cu $H$. pylori este cel mai frecvent asociată gastritei cronice $(54,94 \%)$; în cadrul celor 10 tipuri de gastrită, cele mai frecvente sunt formele purpurice, apoi nodular purpurice şi nodular antrale, la polul opus situându-se gastrita atrofică şi hipertrofică.

Identificarea precoce a infecției este esențială pentru eradicarea bacteriei şi prevenirea apariţiei diferitelor tipuri de gastrită identificate endoscopic.

Asocierile cele mai frecvente decelate endoscopic sunt cu esofagita gr. I, duodenita şi forma purpurică. 